\title{
The aquatic Coleoptera of Prince Edward Island, Canada: new records and faunal composition
}

\author{
Christopher G. Majka \\ Nova Scotia Museum, 1747 Summer Street, Halifax, Nova Scotia, Canada \\ Corresponding author: Christopher G. Majka (c.majka@ns.sympatico.ca)
}

Academic editor: Michael Thomas | Received 16 July 2008 | Accepted 5 August 2008 | Published 17 September 2008

Citation: Majka CG (2008) The aquatic Coleoptera of Prince Edward Island, Canada: new records and faunal composition. In: Majka CG, Klimaszewski J (Eds) Biodiversity, Biosystematics, and Ecology of Canadian Coleoptera. ZooKeys 2: 239-260. doi: 10.3897/zookeys.2.25

\begin{abstract}
The aquatic Coleoptera (Gyrinidae, Haliplidae, Dytiscidae, Hydrophilidae, Elmidae, Dryopidae, Heteroceridae) of Prince Edward Island, Canada is surveyed. Seventy-two species are now known to occur on Prince Edward Island, 26 of which are added to the island's faunal list. Three species, Gyrinus aquiris LeConte, Oulimnius latiusculus (LeConte), and Helichus striatus LeConte, are removed since there are no voucher specimens or published records to substantiate their presence. The name Dineutus horni is designated as an incorrect subsequent spelling of Dineutus hornii Roberts, 1895. The composition of the fauna is briefly discussed, both from regional and zoogeographic perspectives. There is only one introduced species, Helophorus grandis Illiger. Only one third of the aquatic fauna recorded on the neighbouring mainland has been found on Prince Edward Island, perhaps reflecting an island-associated diminution, the paucity of collecting, an area effect, or a combination of all these factors. The island faunas of Prince Edward Island, Cape Breton Island, and insular Newfoundland are compared. Prince Edward Island's is $36 \%$ smaller than the others, in contrast with the island's carabid fauna which is almost identical in magnitude with that of Cape Breton. This might reflect dispersal obstacles, the relative paucity of aquatic habitats on the island, or an insufficient collecting effort. Further research would be desirable, both to better discern the composition of the province's fauna, as well as to monitor the health of aquatic ecosystems in relation to anthropogenic activities.
\end{abstract}

\section{Keywords}

Coleoptera, Prince Edward Island, Canada, Gyrinidae, Haliplidae, Dytiscidae, Hydrophilidae, Elmidae, Dryopidae, Heteroceridae, biodiversity, aquatic invertebrates, nomenclature 


\section{Introduction}

Water beetles are important members of many freshwater aquatic ecosystems. Knowledge of this group of insects in the Maritime Provinces, in general, and on Prince Edward Island, in particular, has been fragmentary. Smetana $(1974,1980,1985,1988)$ made important contributions to knowledge of the Hydrophilidae of the region, Oygur and Wolfe (1991) included information from the Maritime Provinces in their revision of the genus Gyrinus (Gyrinidae), and Larson et al. (2000) comprehensively surveyed the Dytiscidae. In the various chapters pertaining to aquatic Coleoptera in Bousquet (1991), 45 species are reported as occurring on the island. Prince Edward Island has, however, been one of the most poorly known jurisdictions in Canada in terms of its beetle fauna. Collecting effort has been sparse, and much of the material extant in historical collections has remained unexamined and unidentified. The present study makes a contribution towards rectifying this situation by reporting the results of recent collecting of water beetles on the island, as well as the examination of existing historical materials in regional collections.

\section{Methods and conventions}

Voucher specimens of water beetles collected on Prince Edward Island and deposited in various collections were examined. Codens of collections (following Evenhuis 2007) referred to in the text are:

ACPE Agriculture and Agri-Food Canada, Charlottetown, Prince Edward Island, Canada

CGMC Christopher G. Majka Collection, Halifax, Nova Scotia, Canada

CNC Canadian National Collection of Insects, Arachnids, and Nematodes, Ottawa, Ontario, Canada

NSMC Nova Scotia Museum Collection, Halifax, Nova Scotia, Canada

GFC Garth Foster Collection, Ayr, Scotland

UPEI University of Prince Edward Island, Charlottetown, Prince Edward Island, Canada

Note: in some instances specimen records from the UPEI collection are given only for the province as a whole and for the time period 1974-83. These specimens, identified only by catalogue number on their pins, had their detailed collection data recorded in a ledger that was subsequently destroyed by fire. Geo-referenced location coordinates for all collection sites are provided in Appendix 1.

For the purposes of this treatment, northeastern North America is taken to consist of the following jurisdictions: Connecticut, Labrador, Massachusetts, Maine, New Brunswick, Newfoundland, New Hampshire, Nova Scotia, New York, Ontario, Prince Edward Island, Québec, Rhode Island, Saint-Pierre et Miquelon, and Vermont. The 
classification employed follows that of Katovich (2002), Roughley (2000a, 2000b), Roughley and Larson (2000), Shepard (2002a, 2002b), and Van Tassell (2000).

\section{Results}

Seventy-two species of aquatic Coleoptera are known now to occur on Prince Edward Island. Twenty-six species are added to the list of the island's fauna and three species, Gyrinus aquiris LeConte, Oulimnius latiusculus (LeConte), and Helichus striatus LeConte, are removed from the island's faunal list (Table 1). Records for Prince, Queens, and Kings counties (which roughly represent the western, central, and eastern thirds of the island) are indicated. Three species, Peltodytes edentulus (LeConte), Crenitis monticola (Horn), and Stictotarsus griseostriatus (DeGeer), have been recorded only from the province as a whole, thus no further distributional data for them is reported in Table 1. Details of species added to or removed from the island's fauna follow.

Table I. Aquatic Coleoptera of Prince Edward Island

\begin{tabular}{|c|c|c|c|c|}
\hline \multirow[b]{2}{*}{ Species } & \multicolumn{3}{|c|}{ Counties } & \multirow[b]{2}{*}{$\begin{array}{l}\text { Distribution in Northeastern } \\
\text { North America }\end{array}$} \\
\hline & Prince & Queens & Kings & \\
\hline \multicolumn{5}{|l|}{ GYRINIDAE } \\
\hline \multicolumn{5}{|l|}{ Gyrininae } \\
\hline \multicolumn{5}{|l|}{ Enhydrini } \\
\hline Dineutus assimilis Kirby & & 1 & & NS, ON, PE, QC, RI \\
\hline 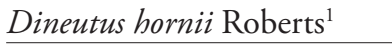 & & 1 & 1 & NB, NS, NY, ON, PE, QC, RI \\
\hline 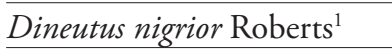 & & & 1 & NB, NS, ON, PE, QC, RI \\
\hline \multicolumn{5}{|l|}{ Gyrinini } \\
\hline Gyrinus affinis Aubé ${ }^{1}$ & & 1 & 1 & $\begin{array}{l}\text { LB, ME, NB, NF, NS, NY, ON, } \\
\text { PE, QC }\end{array}$ \\
\hline Gyrinus bifarius Fall $^{1}$ & 1 & 1 & & $\begin{array}{l}\text { LB, ME, NB, NF, NS, NY, ON, } \\
\text { PE, QC }\end{array}$ \\
\hline Gyrinus confinis LeConte ${ }^{1}$ & & 1 & & $\begin{array}{l}\text { LB, MA, NB, NF, NS, ON, PE, } \\
\text { QC }\end{array}$ \\
\hline Gyrinus fraternus Couper & & 1 & & NS, ON, PE, QC \\
\hline Gyrinus lecontei (Hope) & & 1 & & $\begin{array}{l}\text { MA, ME, NB, NS, ON, PE, QC, } \\
\text { RI }\end{array}$ \\
\hline Gyrinus sayi Aubé & 1 & 1 & & $\begin{array}{l}\text { LB, ME, NB, NF, NS, NY, ON, } \\
\text { PE, QC, RI }\end{array}$ \\
\hline \multicolumn{5}{|l|}{ HALIPLIDAE } \\
\hline Haliplus canadensis Wallis & & & 1 & MA, NS, ON, PE, QC \\
\hline Haliplus cribrarius LeConte & & 1 & 1 & $\begin{array}{l}\text { CT, LB, MA, ME, NB, NF, NH, } \\
\text { NS, NY, ON, PE, QC }\end{array}$ \\
\hline
\end{tabular}




\begin{tabular}{|c|c|c|c|c|}
\hline \multirow[b]{2}{*}{ Species } & \multicolumn{3}{|c|}{ Counties } & \multirow[b]{2}{*}{$\begin{array}{l}\text { Distribution in Northeastern } \\
\text { North America }\end{array}$} \\
\hline & Prince & Queens & Kings & \\
\hline Haliplus immaculicollis Harris & & 1 & 1 & $\begin{array}{l}\text { LB, MA, ME, NB, NF, NH, NS, } \\
\text { ON, QC, PE, PM, RI }\end{array}$ \\
\hline Haliplus longulus LeConte & & 1 & & $\begin{array}{l}\text { MA, NH, NB, NS, NY, ON, PE, } \\
\text { QC, RI }\end{array}$ \\
\hline Peltodytes edentulus (LeConte) $)^{1}$ & & $\bullet$ & & $\begin{array}{l}\text { MA, NB, NH, NS, ON, QC, } \\
\text { PE, RI }\end{array}$ \\
\hline Peltodytes tortulosus Roberts & & 1 & & NH, NS, ON, PE, QC \\
\hline \multicolumn{5}{|l|}{ DYTISCIDAE } \\
\hline \multicolumn{5}{|l|}{ Copelatinae } \\
\hline Copelatus glyphicus (Say) & & & 1 & NF, NS, ON, PE, QC, RI \\
\hline \multicolumn{5}{|l|}{ Laccophilinae } \\
\hline Laccophilus m. maculosus Say & 1 & 1 & & $\begin{array}{l}\text { MA, NB, NH, NS, ON, QC, } \\
\text { PE, RI }\end{array}$ \\
\hline \multicolumn{5}{|l|}{ Hydroporinae } \\
\hline \multicolumn{5}{|l|}{ Hyphydrini } \\
\hline Desmopachria convexa (Aubé) & & 1 & 1 & NB, NS, ON, PE, QC, RI \\
\hline \multicolumn{5}{|l|}{ Bidessini } \\
\hline Liodessus affinis (Say) & & & 1 & $\begin{array}{l}\text { ME, NB, NF, NH, NS, ON, PE, } \\
\text { QC, RI }\end{array}$ \\
\hline \multicolumn{5}{|l|}{ Hydroporini } \\
\hline Hydrocolus stagnalis (G. \& H.) & & 1 & 1 & $\begin{array}{l}\text { ME, NB, NF, NH, NS, ON, PE, } \\
\text { QC }\end{array}$ \\
\hline Hydroporus dentellus Fall & & 1 & 1 & $\begin{array}{l}\text { LB, NB, NH, NS, NY, ON, PE, } \\
\text { QC }\end{array}$ \\
\hline Hydroporus niger Say & & 1 & 1 & $\begin{array}{l}\text { MA, NB, NF, NH, NS, NY, ON, } \\
\text { PE, QC, RI }\end{array}$ \\
\hline Hydroporus notabilis LeConte & & 1 & & $\begin{array}{l}\text { LB, MA, NB, NF, NH, NS, ON, } \\
\text { PE, QC }\end{array}$ \\
\hline $\begin{array}{l}\text { Hydroporus signatus } \\
\text { Mannerheim }\end{array}$ & & & 1 & $\begin{array}{l}\text { LB, NB, NF, NH, NS, ON, PE, } \\
\text { QC, RI }\end{array}$ \\
\hline $\begin{array}{l}\text { Hygrotus impressopunctatus } \\
\text { (Schaller)* }\end{array}$ & 1 & 1 & 1 & $\begin{array}{l}\text { LB, ME, NB, NF, NH, NS, ON, } \\
\text { PE, QC }\end{array}$ \\
\hline Hygrotus picatus (Kirby) & 1 & 1 & 1 & $\begin{array}{l}\text { LB, NB, NF, NS, NY, ON, PE, } \\
\text { QC, RI }\end{array}$ \\
\hline Hygrotus sayi Balfour-Browne & 1 & & 1 & $\begin{array}{l}\text { LB, MA, ME, NB, NF, NH, NS, } \\
\text { NY, ON, PE, QC, RI, VT }\end{array}$ \\
\hline Hygrotus turbidus (LeConte) & & 1 & 1 & $\begin{array}{l}\text { MA, NH, NS, NY, ON, PE, QC, } \\
\text { RI }\end{array}$ \\
\hline
\end{tabular}




\begin{tabular}{|c|c|c|c|c|}
\hline \multirow[b]{2}{*}{ Species } & \multicolumn{3}{|c|}{ Counties } & \multirow[b]{2}{*}{$\begin{array}{l}\text { Distribution in Northeastern } \\
\text { North America }\end{array}$} \\
\hline & Prince & Queens & Kings & \\
\hline $\begin{array}{l}\text { Nebrioporus rotundatus } \\
\text { (LeConte) }\end{array}$ & 1 & 1 & & $\begin{array}{l}\text { LB, NB, NF, NS, ON, PE, QC, } \\
\text { RI }\end{array}$ \\
\hline Neoporus undulatus (Say) & 1 & 1 & 1 & $\begin{array}{l}\text { LB, NB, NF, NS, NY, ON, PE, } \\
\text { QC, RI }\end{array}$ \\
\hline Neoporus dimidiatus (G. \& H.) & & 1 & 1 & $\begin{array}{l}\text { LB, MA, ME, NB, NF, NH, NS, } \\
\text { ON, PE, QC, RI }\end{array}$ \\
\hline $\begin{array}{l}\text { Stictotarsus griseostriatus } \\
\text { (DeGeer)* }\end{array}$ & & $\bullet$ & & $\begin{array}{l}\text { LB, ME, NB, NF, NS, ON, PE, } \\
\text { QC, RI }\end{array}$ \\
\hline \multicolumn{5}{|l|}{ Colymbetinae } \\
\hline \multicolumn{5}{|l|}{ Agabini } \\
\hline Agabus seriatus (Say) ${ }^{1}$ & & 1 & & $\begin{array}{l}\text { LB, MA, ME, NB, NF, NH, NS, } \\
\text { ON, PE, QC }\end{array}$ \\
\hline Agabus ambiguus (Say) & & & 1 & $\begin{array}{l}\text { LB, NB, NF, NH, NS, ON, PE, } \\
\text { QC, RI }\end{array}$ \\
\hline $\begin{array}{l}\text { Agabus anthracinus } \\
\text { Mannerheim }\end{array}$ & & 1 & 1 & $\begin{array}{l}\text { LB, NB, NF, NH, NS, ON, PE, } \\
\text { QC }\end{array}$ \\
\hline Agabus phaeopterus (Kirby) & & 1 & & $\begin{array}{l}\text { LB, NB, NF, NH, NS, ON, PE, } \\
\text { QC }\end{array}$ \\
\hline Agabus subfuscatus Sharp & & 1 & 1 & NB, NS, ON, PE, QC, NF, LB \\
\hline Agabus discolor (Harris) & & 1 & & NB, NS, ON, PE, QC, LB \\
\hline Ilybius biguttulus (Germar) ${ }^{1}$ & & 1 & 1 & $\begin{array}{l}\text { MA, ME, NB, NF, NH, NS, NY, } \\
\text { ON, PE, QC, RI }\end{array}$ \\
\hline Ilybius angustior (Gyllenhal)* & & 1 & & LB, NB, NF, NS, ON, PE, QC \\
\hline Ilybius pleuriticus (LeConte) & & 1 & & $\begin{array}{l}\text { CT, LB, MA, ME, NB, NF, NS, } \\
\text { ON, PE, QC, RI, VT }\end{array}$ \\
\hline \multicolumn{5}{|l|}{ Coptotomini } \\
\hline $\begin{array}{l}\text { Coptotomus longulus lenticus } \\
\text { Hilsenhof }\end{array}$ & & & 1 & $\begin{array}{l}\text { MA, ME, NH, NS, NY, ON, } \\
\text { QC, NB, PE, RI }\end{array}$ \\
\hline \multicolumn{5}{|l|}{ Colymbetini } \\
\hline Colymbetes sculptilis Harris & & 1 & & $\begin{array}{l}\text { LB, NB, NF, NH, NS, NY, ON, } \\
\text { PE, QC, RI }\end{array}$ \\
\hline Rhantus binotatus (Harris) & & 1 & & $\begin{array}{l}\text { LB, ME, NB, NF, NH, NS, ON, } \\
\text { PE, QC, RI }\end{array}$ \\
\hline Rhantus wallisi Hatch ${ }^{1}$ & & 1 & & $\begin{array}{l}\text { LB, NB, NF, NH, NS, ON, PE, } \\
\text { QC }\end{array}$ \\
\hline \multicolumn{5}{|l|}{ Dytiscinae } \\
\hline \multicolumn{5}{|l|}{ Dytiscini } \\
\hline Dytiscus verticalis Say & & & 1 & $\begin{array}{l}\text { MA, ME, NB, NH, NS, NY, } \\
\text { ON, PE, QC, RI }\end{array}$ \\
\hline
\end{tabular}




\begin{tabular}{|c|c|c|c|c|}
\hline \multirow[b]{2}{*}{ Species } & \multicolumn{3}{|c|}{ Counties } & \multirow[b]{2}{*}{$\begin{array}{l}\text { Distribution in Northeastern } \\
\text { North America }\end{array}$} \\
\hline & Prince & Queens & Kings & \\
\hline Dytiscus harrisii Kirby $^{1}$ & 1 & 1 & & $\begin{array}{l}\text { LB, NB, NF, NH, NS, NY, ON, } \\
\text { PE, QC }\end{array}$ \\
\hline Dytiscus fasciventris Say ${ }^{1}$ & & & 1 & $\begin{array}{l}\text { LB, ME, NB, NH, NS, ON, PE, } \\
\text { QC, RI }\end{array}$ \\
\hline Dytiscus dauricus Gebler* & 1 & 1 & 1 & $\begin{array}{l}\text { LB, ME, NF, NB, NS, NY, ON, } \\
\text { PE, QC }\end{array}$ \\
\hline \multicolumn{5}{|l|}{ Hydaticini } \\
\hline Hydaticus aruspex Clark* & 1 & & 1 & $\begin{array}{l}\text { LB, NB, NF, NH, NS, ON, PE, } \\
\text { QC }\end{array}$ \\
\hline \multicolumn{5}{|l|}{ Aciliini } \\
\hline Acilius mediatus (Say) ${ }^{1}$ & & & 1 & $\begin{array}{l}\text { MA, NB, NH, NS, ON, PE, QC, } \\
\text { RI }\end{array}$ \\
\hline Acilius semisulcatus Aubé & 1 & 1 & 1 & $\begin{array}{l}\text { LB, MA, NB, NF, NH, NS, ON, } \\
\text { PE, QC, RI }\end{array}$ \\
\hline Graphoderus perplexus Sharp & & & 1 & $\begin{array}{l}\mathrm{LB}, \mathrm{NB}, \mathrm{NF}, \mathrm{NH}, \mathrm{NS}, \mathrm{ON}, \mathrm{PE}, \\
\mathrm{QC}\end{array}$ \\
\hline \multicolumn{5}{|l|}{ HYDROPHILIDAE } \\
\hline \multicolumn{5}{|l|}{ Helophorinae } \\
\hline Helophorus grandis Illiger $^{1} \dagger$ & & 1 & & $\begin{array}{l}\text { ME, NB, NH, NS, NY, ON, PE, } \\
\text { QC, VT }\end{array}$ \\
\hline $\begin{array}{l}\text { Helophorus orientalis } \\
\text { Motschulsky }{ }^{1 *}\end{array}$ & 1 & 1 & & $\begin{array}{l}\text { CT, MA, ME, NB, NH, NS, NY, } \\
\text { ON, PE, QC, RI }\end{array}$ \\
\hline \multicolumn{5}{|l|}{ Hydrophilinae } \\
\hline \multicolumn{5}{|l|}{ Berosini } \\
\hline Berosus striatus $(\text { Say })^{1}$ & & & 1 & $\begin{array}{l}\text { CT, MA, ME, NB, NH, NS, NY, } \\
\text { ON, PE, QC, RI }\end{array}$ \\
\hline \multicolumn{5}{|l|}{ Anacaenini } \\
\hline Crenitis digesta (LeConte) ${ }^{1}$ & & & 1 & $\begin{array}{l}\text { MA, NB, NH, NS, NY, ON, PE, } \\
\text { QC }\end{array}$ \\
\hline Crenitis monticola (Horn) ${ }^{1}$ & & $\bullet$ & & NB, NH, NS, PE, QC \\
\hline Anacaena limbata (Fabricius) ${ }^{1}$ & & 1 & & $\begin{array}{l}\text { ME, NB, NF, NH, NS, NY, ON, } \\
\text { PE, QC }\end{array}$ \\
\hline \multicolumn{5}{|l|}{ Laccobiini } \\
\hline Laccobius reflexipennis Cheary $^{1}$ & & 1 & & NB, NS, ON, PE, QC \\
\hline \multicolumn{5}{|l|}{ Hydrophilini } \\
\hline $\begin{array}{l}\text { Enochrus ochraceus } \\
\text { (Melsheimer) })^{1}\end{array}$ & & 1 & & $\begin{array}{l}\text { MA, ME, NB, NF, NH, NS, } \\
\text { ON, PE, QC, RI }\end{array}$ \\
\hline Enochrus hamiltoni (Horn) ${ }^{1}$ & & 1 & 1 & $\begin{array}{l}\text { MA, ME, NB, NF, NH, NS, NY, } \\
\text { ON, PE, QC, RI }\end{array}$ \\
\hline
\end{tabular}




\begin{tabular}{|c|c|c|c|c|}
\hline \multirow[b]{2}{*}{ Species } & \multicolumn{3}{|c|}{ Counties } & \multirow[b]{2}{*}{$\begin{array}{l}\text { Distribution in Northeastern } \\
\text { North America }\end{array}$} \\
\hline & Prince & Queens & Kings & \\
\hline Hydrobius fuscipes (Linnaeus) ${ }^{1 *}$ & & 1 & & $\begin{array}{l}\text { CT, LB, MA, ME, NB, NF, NH, } \\
\text { NS, NY, ON, PE, QC, RI, VT }\end{array}$ \\
\hline Hydrobius melaenus (Germar) ${ }^{1}$ & & & 1 & $\begin{array}{l}\text { CT, MA, ME, NB, NH, NS, NY, } \\
\text { ON, PE, QC, RI, VT }\end{array}$ \\
\hline Hydrochara obtusata (Say) ${ }^{1}$ & 1 & 1 & & $\begin{array}{l}\text { CT, MA, ME, NB, NH, NS, NY, } \\
\text { ON, PE, QC, RI, VT }\end{array}$ \\
\hline Tropisternus glaber Herbst ${ }^{1}$ & & 1 & 1 & $\begin{array}{l}\text { MA, NB, NH, NS, NY, ON, PE, } \\
\text { QC, RI }\end{array}$ \\
\hline Tropisternus mixtus (LeConte) $)^{1}$ & & & 1 & $\begin{array}{l}\text { ME, NB, NH, NS, NY, ON, PE, } \\
\text { QC, RI }\end{array}$ \\
\hline \multicolumn{5}{|l|}{ ELMIDAE } \\
\hline \multicolumn{5}{|l|}{ Elminae } \\
\hline \multicolumn{5}{|l|}{ Elmini } \\
\hline Dubiraphia quadrinotata (Say) & 1 & & & $\begin{array}{l}\text { ME, NB, NH, NS, NY, ON, PE, } \\
\text { QC, PE, RI, VT }\end{array}$ \\
\hline Optioservus fastiditus (LeConte) & & 1 & 1 & $\begin{array}{l}\text { NB, NF, NH, NS, NY, ON, PE, } \\
\text { QC }\end{array}$ \\
\hline Optioservus ovalis (LeConte) & & 1 & & $\begin{array}{l}\text { CT, LB, ME, NB, NH, NS, NY, } \\
\text { ON, PE, QC, VT }\end{array}$ \\
\hline Stenelmis crenata (Say) & & & 1 & $\begin{array}{l}\text { MA, ME, NB, NF, NH, NS, NY, } \\
\text { ON, PE, QC, RI }\end{array}$ \\
\hline \multicolumn{5}{|l|}{ HETEROCERIDAE } \\
\hline \multicolumn{5}{|l|}{ Heterocerinae } \\
\hline \multicolumn{5}{|l|}{ Heterocerini } \\
\hline $\begin{array}{l}\text { Lantenarius brunneus } \\
\text { (Melsheimer) }\end{array}$ & 1 & & & $\begin{array}{l}\text { MA, ME, NH, NS, NY, ON, PE, } \\
\text { QC, VT, RI }\end{array}$ \\
\hline Totals & 16 & 49 & 39 & \\
\hline
\end{tabular}

Notes: Distributional information is derived from Chandler (2001), Dearborn and Donahue (1993), Downie and Arnett (1996), Larson et al. (2000), Larson and Roughley (1991), LeSage (1991a, 1991b, 1991c), Roughley (1991a, 1991b, 1991c), Sikes (2004), Smetana (1988), and unpublished data.

Regional Distribution: CT, Connecticut; LB, Labrador; MA, Massachusetts; ME, Maine; NB, New Brunswick; NF, insular Newfoundland; NH, New Hampshire; NS, Nova Scotia; NY, New York; ON, Ontario; PE, Prince Edward Island; QC, Québec; RI, Rhode Island; PM, Saint-Pierre et Miquelon; VT, Vermont.

${ }^{1}$, Species newly recorded from Prince Edward Island in the present account; *, Holarctic species; $\dagger$, introduced Palaearctic species; $\bullet$, provincial record (no locality or county information available). 


\section{Gyrinidae}

Adults glide on the surface of ponds, lakes, and slow-moving rivers. They often congregate and swim rapidly in circles when alarmed, giving rise to their common name of whirligig. Adults are scavengers, feeding on dead and dying insects on the water surface, whereas larvae are predaceous on insect larvae and nymphs (Roughley 2000a).

\section{Dineutus hornii Roberts, 1895}

Kings Co.: Woodville Mills, 16.IX.2002, C.G. Majka, beaver pond, (3, CGMC). Queens Co.: Hillsboro River, 22.VI.1981, V. Friesen, (7, UPEI).

Dineutus hornii is newly recorded on Prince Edward Island. Species of Dineutus are found on the surface ponds, streams, lakes and rivers where they often form large rafts of individuals (Roughley 2000a).

Roberts (1895, pp 284) described this species as Dineutus hornii, the specific epithet spelled with two "i's". Subsequently some authors (i.e. Leng 1920; Roughley 1991b; Laplante et al. 1991; Dearborn and Donahue 1993; Downie and Arnett 1996; Chandler 2001) dropped the second " $i$ ", incorrectly spelling the name "Dineutus horni". Accordingly the name Dineutus horni is designated as an incorrect subsequent spelling of Dineutus hornii Roberts, 1895 (Article 33.3, ICZN 1999).

Dineutus nigrior Roberts, 1895

Kings Co.: Woodville Mills, 16.IX.2002, C.G. Majka, beaver pond, (1, CGMC). Dineutus nigrior is newly recorded on Prince Edward Island.

Gyrinus aquiris LeConte, 1868

This species was reported from Prince Edward Island by Roughley (1991a), however, there are no voucher specimens from PEI in any collection consulted, nor was the species listed from the province by Fall (1922) or Oygur and Wolfe (1991). Consequently this species is removed from the faunal list of Prince Edward Island.

Gyrinus affinis Aubé, 1838

Kings Co.: Upton, 6.VI.1953, F.M. Cannon, (1, ACPE). Queens Co.: Charlottetown, 20.VI.1936, lily pond, UPEI; Vernon River, MacMillan's Pond, 3.VI.1970, R. Wenn, (1, UPEI). 
Newly recorded on Prince Edward Island, this species is found in both lentic (58.8\%) and lotic (41.2\%) environments (Oygur and Wolfe 1991).

Gyrinus bifarius Fall, 1922

Prince Edward Island: locality data lost, 1974-1983, (1, UPEI). Prince Co.: Enmore, 21.V.1981, V. Friesen, (1, UPEI). Queens Co.: Mount Herbert, 31.V.1923, J.R. Mutch, (4, UPEI); Officer's Pond, 19.IX.1972, R. Edwards, (1, UPEI); Vernon River, MacMillan's Pond, 3.VI.1970, R. Wenn, (1, UPEI).

Newly recorded on Prince Edward Island, this species is found in both lentic (25.7\%) and lotic (74.3\%) environments (Oygur and Wolfe 1991).

Gyrinus confinis LeConte, 1868

Queens Co.: Vernon River, MacMillan's Pond, 3.VI.1970, R. Wenn, (1, UPEI).

Newly recorded on Prince Edward Island, this species is found primarily in lentic (91.7\%) and occasionally lotic (8.3\%) environments (Oygur and Wolfe 1991).

\section{Haliplidae}

Species of Haliplus and Peltodytes are found in small ponds, lakes, and quiet streams where they are frequently observed crawling in algal mats or other vegetation. Adults eat insect eggs, algae, and polyps of Hydrozoa whereas larvae are algophilous (Roughley 2000b).

Haliplus canadensis Wallis, 1933

Kings Co.: Dingwell's Mills, 26.VI.1985, L. LeSage, Typha zone along river, (1, CNC). The species was recorded from Prince Edward Island by Vondel (2005), however, the collection data for this species have not previously been published.

Haliplus cribrarius LeConte, 1850

Kings Co.: Dingwell's Mills, 26.VI.1985, L. LeSage, Typha zone along river, (1, CNC); (no locality recorded), Kings, 13.VII.1988, Y. Bousquet, (1, CNC). Queens Co.: Vernon River, MacMillan's Pond, 3.VI.1970, R. Wenn, (1, UPEI).

The species was recorded from Prince Edward Island by Vondel (2005), however, the collection data for this species have not previously been published. 
Haliplus longulus LeConte, 1850

Queens Co.: Brackley Beach, 26.VI.1985, L. LeSage, pond with filamenous algae and rotting vegetation, (1, CNC); Glenroy, 26.VI.1985, L. LeSage and R. Rocho, ditch along railroad, (1, CNC); Harrington, 27.VI.1985, L. LeSage, CNC; north of Pleasant Grove, 27.VI.1985, L. LeSage, (1, CNC).

The species was recorded from Prince Edward Island by Vondel (2005), however, the collection data for this species have not previously been published.

Peltodytes edentulus (LeConte, 1863)

Prince Edward Island: locality data lost, 1974-1983, (1, UPEI).

Peltodytes edentulus is newly recorded on Prince Edward Island.

Peltodytes tortulosus Roberts, 1913

Prince Edward Island: locality data lost, 1974-1983, (1, UPEI). Queens Co.: Vernon River, MacMillan's Pond, 3.VI.1970, R. Wenn, (1, UPEI); Cavendish, duneland trail, 4.IX.1999, T. Huxley, (1, GFC).

The species was recorded from Prince Edward Island by Vondel (2005), however, the collection data for this species have not previously been published.

\section{Dytiscidae}

The Dytiscidae are a diverse and species-rich family of predaceous water beetles. They occur in many aquatic environments.

Agabus seriatus (Say, 1823)

Queens Co.: St. Patricks, 18.VIII.2002, C.G. Majka, along small stream in moss, (4, CGMC).

Newly recorded on Prince Edward Island, this species is found in springs, small, creeks occasionally along the margins of small rivers on mineral substrates or in mats of vegetation at the edge of flowing water (Larson et al. 2000). 
Ilybius biguttulus (Germar, 1824)

Prince Edward Island: locality data lost, 1974-1983, (3, UPEI); Kings Co.: Valleyfield, 8.VII.1982, V. Friesen, by stream, (1, UPEI); Queens Co.: Charlottetown, 25.VI.1978, L.S. Thompson, (1, ACPE); Watervale, 29.VII.1970, R. Wenn, pond edge, (1, UPEI).

Newly recorded on Prince Edward Island, this species is found in sun-warmed, permanent lentic habitats in dense aquatic vegetation (Larson et al. 2000).

Rhantus wallisi Hatch, 1963

Queens Co.: locality data lost, VII.1979, L.S. Thompson, (1, ACPE).

Newly recorded on Prince Edward Island, this species is found in ponds in wooded areas, in sun-warmed, vegetation-rich margins (Larson et al. 2000).

\section{Dytiscus harrisii Kirby, 1837}

Prince Co.: Conway Narrows, 1.VIII.1970, U. Grigg, (1, NSMC); Queens Co.: Rice Pt., 12.VII.1983, M.E.M. Smith; Rice Pt., 13.VII.1983, M.E.M. Smith, (1, ACPE).

Newly recorded on Prince Edward Island, this species is found in shallow, warm permanent ponds and sedge marshes; specimens have also been taken in beaver ponds and at the edges of slow-moving boreal streams (Larson et al. 2000).

Dytiscus fasciventris Say, 1824

Prince Edward Island: locality data lost, 1974-1983, (5, UPEI); Kings Co.: Launching, 26.VIII.2003, C.G. Majka, (1, CGMC).

Newly recorded on Prince Edward Island, this species is found in a variety of ponds and marshes, in particular those with sedges; it is an avid predator of early spring mosquito larvae (Larson et al. 2000).

Acilius mediatus (Say, 1823)

Kings Co.: Souris, 29.VI.1993, L.S. Thompson, (1, ACPE).

Newly recorded on Prince Edward Island, this species is found in small forest pools, generally with bare, peaty bottoms; also in pools or adjacent to slow-flowing, brown-water streams (Larson et al. 2000). 


\section{Hydrophilidae}

The aquatic members of the Hydrophilidae (the present account does not treat terrestrial species in the subfamily Sphaeridiinae) occur in a wide variety of aquatic environments, most of them in standing water and lentic habitats. Most species are scavengers, feeding on various kinds of decaying plant material, or else they feed on living plants such as algae (Smetana 1988).

\section{Helophorus grandis Illiger, 1798}

Queens Co.: Harrington, 14.VI.2004, C. Noronha, barley field, pitfall trap, (1, ACPE); Mount Herbert, Orphanage Pond, 30.V.1923, J.R. Mutch, (1, UPEI); West Royalty, 16.V.1983, L.S. Thompson, (1, ACPE); Wood Islands, 30.VI.2003, C.G. Majka, (1, CGMC).

Newly recorded on Prince Edward Island, this species favours temporary pools and muddy or weedy margins of ponds or lakes (Smetana 1988).

This adventive, Palaearctic species was first reported in North America by Darlington (1927). Smetana (1985) examined specimens from as early as 1904 from Montreal, although Brown (1940) noted a specimen from Chicoutimi, Québec, from the "second" collection of Provancher acquired sometime between 1877 and 1892. The earliest records from New Brunswick are in 1926 and from Nova Scotia in 1947 (Smetana 1985) so the collection from 1923 on Prince Edward Island establishes a new early timeline for $H$. grandis in the Maritime Provinces of Canada.

Helophorus orientalis Motschulsky, 1860

Prince Co.: Summerside, 19.VI.1992, M.E.M. Smith, potato field, pitfall trap, (5, ACPE); Queens Co.: New Glasgow, 13.VII.2002, C.G. Majka, meadow, (1, CGMC); St. Patricks, 18.VIII.2002, in wet moss beside small stream, (2, CGMC); St. Patricks, 14.VII.2002, in wet moss beside small stream, (9, CGMC).

Newly recorded on Prince Edward Island, this Holarctic species is found in a wide range of lotic and lentic environments, however, shallow temporary pools with plenty of vegetation are preferred (Smetana 1988).

Berosus striatus (Say, 1825)

Kings Co.: Woodville Mills, 30.VI.2003, C.G. Majka, beaver pond, (1, CGMC).

Newly recorded on Prince Edward Island, the species favours a wide variety of aquatic habitats favouring margins of deeper waters, particularly those with sandy bottoms and lots of debris (Smetana 1988). 
Crenitis digesta (LeConte, 1855)

Kings Co.: Woodville Mills, 30.VI.2003, C.G. Majka, beaver pond, (4, CGMC).

Newly recorded on Prince Edward Island. It is found in both lotic and lentic environments, however, little is known about its habitat preferences (Smetana 1988).

Crenitis monticola (Horn, 1890)

Prince Edward Island: locality data lost, 1974-1983, (1, UPEI).

Newly recorded on Prince Edward Island, this species is found in both lotic and lentic environments, however, little is known about its habitat preferences (Smetana 1988).

“Anacaena limbata (Fabricius, 1792)"

Queens Co.: Millvale, 25.VI.2003, C.G. Majka, old mill pond, (2, CGMC); Millvale, 15.VIII.2004, C.G. Majka, old mill pond, (7, CGMC); St. Patricks, 18.VIII.2002, C.G. Majka, in wet moss beside small stream, (3, CGMC); St. Patricks, 14.VII.2002, C.G. Majka, in wet moss beside small stream, (3, CGMC); Vernon River, MacMillan's Pond, 3.VI.1970, R. Wenn, pond, (1, UPEI).

Newly recorded on Prince Edward Island, this species favours shallow standing water or margins of slow-flowing creeks with vegetation. It is also frequently found in semi-aquatic habitats (Smetana 1988).

The zoogeographic status of this species is unclear. Smetana (1988) regarded it as an apparently Palaearctic species introduced to North America. He also drew attention to the fact that it appeared that two species, A. lutescens (Stephens 1829) and A. limbata, were being confused under the name of $A$. limbata in North America. Albrecht Komarek (pers. comm.), who is revising the genus worldwide, points out that while A. limbata and A. lutescens are readily separable in Europe, North American specimens cannot unambiguously be assigned to either species. He believes that North American specimens may represent a separate, undescribed "cryptic" species in the lutescens complex. Morphological examinations cannot resolve the problem and it may require molecular phylogenetic analysis in order to discern the nature of this "species." Thus, in the present treatment, I provisionally treat it as a Nearctic species in the lutescens complex whose status has yet to be fully discerned.

\section{Laccobius reflexipennis Cheary, 1971}

Prince Edward Island: locality data lost, 1974-1983, (1, UPEI); Queens Co.: St. Patricks, 14.VII.2002, C.G. Majka, in wet moss beside small stream, (1, CGMC). 
Laccobius reflexipennis is newly recorded on Prince Edward Island. No information on the bionomics of this species is available. Species of Laccobius are found in both lotic and lentic environments (Smetana 1988).

Enochrus ochraceus (Melsheimer, 1846)

Queens Co.: Watervale, 29.VII.1970, R. Wenn, aquatic vegetation, (1, UPEI).

Newly recorded on Prince Edward Island, this species prefers shallow water with abundant organic debris (Smetana 1988).

Enochrus hamiltoni (Horn, 1890)

Kings Co.: Woodville Mills, 30.VI.2003, C.G. Majka, beaver pond, (4, CGMC); Queens Co.: St. Patricks, 18.VIII.2002, C.G. Majka, in wet moss beside small stream, (2, CGMC); Wood Islands, 30.VI.2003, C.G. Majka, (1, CGMC).

Newly recorded on Prince Edward Island, this is a common species, abundant in a wide range of aquatic habitats (Smetana 1988).

Hydrobius fuscipes (Linnaeus, 1758)

Prince Edward Island: locality data lost, 1974-1983, (9, UPEI); Queens Co.: Watervale, 29.VII.1970, R. Wenn, aquatic vegetation, (1, UPEI); Harrington, 22.VI.1981, K. MacDonald, pond, (1, UPEI); West Royalty, 25.VI.1970, R. Wenn, light trap, North Rustico, 26.VI.2003, C.G. Majka, seashore, (1, CGMC).

Newly recorded on Prince Edward Island, this species is found in a wide range of aquatic habitats, particularly shallow, stagnant pools with plant debris; also in swampy habitats and Sphagnum bogs (Smetana 1988).

Hydrobius melaenus (Germar, 1824)

Kings Co.: Woodville Mills, 23.VII.2001, C.G. Majka, under stone beside small stream, (1, CGMC).

Newly recorded on Prince Edward Island, this species prefers running water habitats in places protected from currents (Smetana 1988). 
Hydrochara obtusata (Say, 1823)

Prince Edward Island: locality data lost, 1974-1983, (2, UPEI); Prince Co.: Conway Narrows, 23.VIII.1970, U. Grigg, (1, NSMC); Queens Co.: Charlottetown, 1952, F.M. Cannon, (1, ACPE).

Newly recorded on Prince Edward Island, this species is found in a wide range of aquatic habitats, particularly in shallow water with rich vegetation. It is occasionally found under stones and wood at the edge of water (Smetana 1988).

\section{Tropisternus glaber Herbst, 1797}

Prince Edward Island: locality data lost, 1974-1983, (1, UPEI); Kings Co.: Woodville Mills, 16.VIII.2003, C.G. Majka, beaver pond, (1, CGMC); Queens Co.: Watervale, 29.VII.1970, R. Wenn, vegetation at edge of pond, (1, UPEI); locality data not recorded, VII.1979, L.S. Thompson, (1, ACPE).

Newly recorded on Prince Edward Island, this species frequents a wide-range of aquatic habitats, particularly lentic ones; often in marshes, swamps and bogs (Smetana 1988).

Tropisternus mixtus (LeConte, 1855)

Kings Co.: Woodville Mills, 30.VI.2003, C.G. Majka, beaver pond, (1, CGMC).

Newly recorded on Prince Edward Island, this species prefers cool and clean aquatic habitats, mostly in standing water; occasionally around the edges of running water (Smetana 1988).

\section{Elmidae}

Adults and larvae of the Elmidae are aquatic beetles found attached to rocks and other substrates. All the species on Prince Edward Island inhabit rapid, cool, and well-oxygenated streams where they feed on algae or detritus (Shepard 2002a).

\section{Oulimnius latiusculus (LeConte, 1866)}

This species was recorded from Prince Edward Island by LeSage (1991c), however, there are no voucher specimens in any collection consulted, and no published records of this species from the province. It is not listed as occurring in PEI by Brown (1983b). Laurent LeSage (pers. comm.) was unable to determine the source of the original report. Consequently this species is removed from the faunal list of Prince Edward Island. 


\section{Dryopidae}

The aquatic species of this family found in North America are riparian where they are found crawling on various substrates in streams. Adults and larvae are herbivorous (Shepard 2002b).

\section{Helichus striatus striatus LeConte, 1852}

Although this species was recorded from Prince Edward Island by LeSage (1991b) there are no voucher specimens in any collection consulted, nor are there published records of this species from the province. It is not listed as occurring in PEI by Brown (1983a). Laurent LeSage (pers. comm.) was unable to determine the source of the original report. Consequently this species is removed from the faunal list of Prince Edward Island.

\section{Heteroceridae}

Adult heterocerids are commonly associated with riparian or other water-edge habitats where they excavate tunnels in sand or mud. They feed on algae, plankton, and organic matter (Katovich 2002).

Lantenarius brunneus (Melsheimer, 1844)

Prince Co.: Scales Pond, 12.VII.1988, Y. Bousquet, (1, CNC).

The species was recorded from Prince Edward Island by LeSage (1991a), however, the collection data for this species has not previously been published.

\section{Discussion}

Seventy-two species of water beetles are known from Prince Edward Island: ten gyrinids, six haliplids, 40 dytiscids, 14 hydrophilids, four elmids, and one heterocerid (Table 1). Of these, 26 species are newly recorded from Prince Edward Island: five gyrinids, one haliplid, six dytiscids, and 14 hydrophilids. Three species, Gyrinus aquiris LeConte, Oulimnius latiusculus (LeConte), and Helichus striatus LeConte, have been removed from the faunal list of Prince Edward Island since no voucher specimens or published records of these species on PEI could be located. There are records of 49 species from Queens County, 39 from Kings County and 16 from Prince County. These regional differences may be attributable to variations in collecting effort between these three portions of the province. Alternatively they may 
reflect anthropogenic influences on the fauna since Prince County is the most heavily farmed portion of the island and in recent years the area has experienced a number of well-documented fish-kills due to pesticide run off.

The composition of the fauna reflects that of the Maritime Provinces as a whole. All the species found on Prince Edward Island have also been recorded in Nova Scotia, and all but six [Dinetus assimilis Kirby, Haliplus canadensis Wallis, Peltodytes tortulosus Roberts, Copelatus glyphicus (Say), Hygrotus turbidus (LeConte), and Lantenarius brunneus (Melsheimer)] have also been recorded in New Brunswick. The absence of these six species in the latter province is likely attributable to a lack of collection effort in New Brunswick, a relatively poorly investigated province within Canada in terms of its beetle fauna. In general, Prince Edward Island's fauna appears to be relatively homogeneous in composition. For example, of the 40 species of Dytiscidae found on Prince Edward Island, all are broadly distributed in the Atlantic Maritime Ecozone and all 40 are also found in the neighbouring Boreal Shield and Mixed Plains Ecozones (Larson et al. 2000).

The Nearctic component of the fauna is made up of 64 species (89\%), the Holarctic component of 7 species (10\%), and the introduced, Palaearctic component of one species (1\%). The proportion of Holarctic Carabidae on Prince Edward Island (10.5\%) is very similar (Majka et al. 2008), however, the proportion of adventive aquatic species in comparison to the overall adventive beetle fauna of Prince Edward Island (21.2\%, unpublished data) is very slight.

As is typical in the case with island faunas, that of Prince Edward Island is diminished in comparison with that of the neighbouring mainland. Table 2 indicates that the 71 native water beetles found on Prince Edward Island are only $34 \%$ of the

Table 2. Composition of the Maritime Provinces aquatic Coleoptera

\begin{tabular}{lcccccc:ccc|c}
\hline Family & NB & NS & CB & PEI & SI & MP & N & H & P & NF \\
\hline Gyrinidae & 18 & 20 & 9 & 9 & 0 & 24 & 23 & 1 & & 10 \\
\hline Haliplidae & 10 & 12 & 4 & 6 & 1 & 13 & 12 & 1 & & 4 \\
\hline Dytiscidae & 83 & 89 & 62 & 38 & 9 & 104 & 91 & 13 & & 80 \\
\hline Hydrophilidae* & 38 & 39 & 27 & 14 & 3 & 43 & 35 & 7 & 1 & 13 \\
\hline Hydraenidae & 3 & 2 & 1 & 0 & 0 & 3 & 3 & & & 1 \\
\hline Elmidae & 10 & 12 & 7 & 4 & 0 & 13 & 13 & & & 5 \\
\hline Dryopidae & 3 & 2 & 0 & 0 & 0 & 3 & 2 & & 1 & 1 \\
\hline Heteroceridae & 5 & 4 & 1 & 1 & 1 & 6 & 6 & & & 0 \\
\hline Psephenidae & 2 & 2 & 0 & 0 & 0 & 2 & 2 & & & 0 \\
\hline Total & 172 & 182 & 111 & 72 & 14 & 211 & 187 & 22 & 2 & 114 \\
\hline
\end{tabular}

Notes: NB, New Brunswick; NS, Nova Scotia; CB, Cape Breton; PEI, Prince Edward Island; SI, Sable Island; MP, Maritime Provinces; NF, insular Newfoundland; N, Nearctic; H, Holarctic; P, Palaearctic. Information is derived from Larson et al. (2000), Larson and Roughley (1991), LeSage (1991a, 1991b, 1991c), Roughley (1991a, 1991b, 1991c), Smetana (1988), Vondel (2005), and unpublished data. Information from Newfoundland is provided as a basis of comparison.

* excluding the Sphaeridiinae 
total native mainland fauna (209 species) recorded in the Maritime Provinces. This may represent an island-associated diminution, the paucity of collecting, an area effect, or a combination of all these factors. In comparison, Majka and McCorquodale (2006) found that Prince Edward Island had 39\% of the native Maritime Provinces fauna of Coccinellidae, Majka and Jackman (2006) found 40\% of Maritime species of Mordellidae, Majka et al. (2007) found 32\% of the native Maritime Cerambycidae, and Majka et al. (2008) found $49 \%$ of the native Maritime Carabidae that occur on Prince Edward Island.

In an examination of the native Carabidae of insular portions of Atlantic Canada, Majka et al. (2008) found that despite significantly different land areas, and different distances to the neighbouring continental mainland, the island faunas of Prince Edward Island (with a land area of 5,660 $\mathrm{km}^{2}$ and $13 \mathrm{~km}$ from the mainland) and insular Newfoundland (with a land area of $111,390 \mathrm{~km}^{2}, 18 \mathrm{~km}$ distant from Labrador and $110 \mathrm{~km}$ from Cape Breton Island), are very similar (144 and 148 species respectively) despite differences in composition. The fauna of Cape Breton Island (with a land area of $10,311 \mathrm{~km}^{2}$ and $1.5 \mathrm{~km}$ from the mainland) was $16 \%$ greater consisting of 170 species. In the case of aquatic beetles the situations is reversed. Table 2 indicates that the size of the Cape Breton and Newfoundland faunas are very similar (111 and 114 species respectively), whereas that of Prince Edward Island is 36\% smaller consisting of 72 species. This difference could be due to several factors. It could be that the 13+ $\mathrm{km}$ wide Northumberland Strait has been a barrier to the dispersal of some species of aquatic Coleoptera; or the comparative lack of certain aquatic habitats on the island (which has only one freshwater lake and only relatively short watersheds); or the comparative lack of collecting on Prince Edward Island; or a combination of all these factors. There are, however, more than 800 millponds and a large number of springs on the island, many of which have been little or not at all investigated in terms of their aquatic beetle fauna. Further research in these habitats may yield additional species for the Prince Edward Island fauna.

As a rather different point of comparison, there have been 14 species of water beetles recorded on Sable Island (Table 2) which is circa $50 \mathrm{~km}^{2}$ in area and is $160 \mathrm{~km}$ from the Nova Scotia mainland, although one of these species, Hydrophilus triangularis Say, was recorded only as a stray (Wright 1989).

Helophorus grandis is the only adventive water beetle found on Prince Edward Island and it is noteworthy that the collection from 1923 establishes a new early timeline for this species in the Maritime Provinces. Its collection in pitfall traps in agricultural fields may be indicative of a mode of introduction. Brown (1950) and Lindroth (1957) developed the theory that ships' dry ballast was a probable source of entry of many adventive ground-dwelling Coleoptera. It is possible that $\mathrm{H}$. grandis might belong to the suite of adventive beetles that were introduced to North America via this mechanism.

Almost all of the knowledge that we have about the Prince Edward Island aquatic beetle fauna has been acquired recently. Of the 72 species recorded to date, all but eight (Gyrinus affinis, Gyrinus bifarius, Laccophilus m. maculosus Say, Ilybius angustior 
(Gyllenhal), Colymbetes sculptilis Harris, Rhantus binotatus (Harris), Acilius semisulcatus Aubé, and Helophorus grandis) have first been recorded in the last 50 years (and these eight species have also been recorded subsequently). Thus the very limited historical information on these aquatic insects on the island means that it is not possible to determine historical population trends.

\section{Conclusions}

Despite the many additions to the faunal list of Prince Edward Island, the preceding account clearly represents only a preliminary treatment of the aquatic beetles of the province. The comparative dearth of collecting means that it is likely that additional species remain to be found. As well, the detailed distribution of these species on the island remains to be discerned. Yves Alarie at Laurentian University has been conducting surveys on Prince Edward Island and it is to be expected that the results of his work will yield additional information. As well, D. Giberson and her students at the University of Prince Edward Island, continue to investigate aquatic habitats, programs that will also doubtless yield important comparative information on aquatic insects and invertebrates. Prince Edward Island has experienced a long history of anthropogenic activities, which in the past 60 years has included the extensive use of insecticides and other biocides. Ongoing surveying of populations of aquatic insects such as beetles, may provide avenues of monitoring the health of aquatic ecosystems and of environmental change.

\section{Acknowledgments}

Sincere thanks to Christine Noronha and Mary Smith (Agriculture and Agri-Food Canada, Charlottetown), Yves Bousquet and Laurent LeSage (Agriculture and AgriFood Canada, Ottawa), Bernhard J. van Vondel (Naturhistorisch Museum Rotterdam), Ursula Grigg (Nova Scotia Museum), Donna Giberson (University of Prince Edward Island), and J. Robert Mutch (deceased) (Charlottetown) for making specimens and records available. Thanks also to Yves Alarie (Laurentian University), Rex Kenner (Spencer Entomological Museum), Albrecht Komarek (Naturhistorisches Museum Wien), David Larson (formerly at Memorial University), Robert Roughley (University of Manitoba), Andrew Short (University of Kansas), and Eileeen Van Tassell (formerly at Michigan State University) for their assistance with determinations and taxonomic questions. Sincere thanks to Henry Hagedorn (Journal of Insect Science) for his excellent editorial assistance with an earlier version of the manuscript. Bernhard van Vondel and Donna Giberson reviewed the manuscript and made many constructive suggestions for its improvement. Thanks to David Christianson, Calum Ewing, Andrew Hebda and the Board of Governors of the Nova Scotia Museum for their assistance and encouragement. 


\section{References}

Bousquet Y (Ed) (1991) Checklist of Beetles of Canada and Alaska. Agriculture Canada Publication 1861/E: 1-430.

Brown HP (1983a) A catalogue of the Coleoptera of America north of Mexico. Family Dryopidae. United States Department of Agriculture, Agriculture Handbook: 529-549.

Brown HP (1983b) A catalogue of the Coleoptera of America north of Mexico. Family Elmidae. United States Department of Agriculture, Agriculture Handbook: 529-550.

Brown WJ (1940) Notes on the American distribution of some species of Coleoptera common to the European and North American continents. The Canadian Entomologist 72: 65-78.

Brown WJ (1950) The extralimital distribution of some species of Coleoptera. The Canadian Entomologist 82: 197-205.

Chandler DS (2001) University of New Hampshire Insect and Arachnid Collections. http:// insectcoll.unh.edu/ [accessed 26.IX.2008]

Darlington PJ, Jr (1927) Helophorus aquaticus L. in America. Psyche 34: 174-175.

Dearborn RG, Donahue CP (1993) An annotated list of insects collected and recorded by the Maine Forest Service: Order Coleoptera, Beetles. Maine Forest Service Technical Report 32: 1-101.

Downie NM, Arnett RH, Jr (1996) The beetles of northeastern North America. Sandhill Crane Press, Gainesville, Florida, 1721 pp.

Evenhuis NL (2007) Abbreviations for insect and spider collections of the world. http://hbs. bishopmuseum.org/codens/codens-inst.html [accessed 26.IX.2008]

Fall HC (1922) The North American species of Gyrinus (Coleoptera). Transactions of the American Entomological Society 47: 269-306.

ICZN [International Code of Zoological Nomenclature]. 1999. International Commission on Zoological Nomenclature, Fourth edition. The Natural History Museum, London, 306 pp. http://www.iczn.org/iczn/index.jsp [accessed 26.IX.2008]

Katovich K (2002) Heteroceridae MacLeay 1825. In: Arnett RH, Jr, Thomas MC, Skelley PE, Frank JH (Eds) American Beetles, 2. Polyphaga: Scarabaeoidea through Curculionoidea. CRC Press, Boca Raton, 127-132.

Laplante S, Bousquet Y, Bélanger P, Chantal C (1991) Liste des espèces de Coléoptères du Québec. Fabreries supplément 6: 1-236.

Larson DJ, Alarie Y, Roughley RE (2000) Predaceous diving beetles Coleoptera: Dytiscidae. of the Nearctic region, with emphasis on the fauna of Canada and Alaska. NRC Research Press, Ottawa, 982 pp.

Larson DJ, Roughley RE (1991) Family Dytiscidae: predaceous diving beetles. In: Bousquet Y (Ed) Checklist of Beetles of Canada and Alaska. Agriculture Canada Publication 1861/E: 62-72.

Leng CW (1920) Catalogue of the Coleoptera of America north of Mexico. John D. Sherman Jr, Mount Vernon, New York, 470 pp.

LeSage L. (1991a) Family Heteroceridae: variegated mud-loving beetles. In: Bousquet Y (Ed) Checklist of Beetles of Canada and Alaska. Agriculture Canada Publication 1861/E: 169-170.

LeSage L (1991b) Family Dryopidae: long-toed water beetles. In: Bousquet Y (Ed) Checklist of Beetles of Canada and Alaska. Agriculture Canada Publication 1861/E: 171-172. 
LeSage L (1991c) Family Elmidae: riffle beetles. In: Bousquet Y (Ed) Checklist of Beetles of Canada and Alaska. Agriculture Canada Publication 1861/E: 172-173.

Lindroth CH (1957) The faunal connections between Europe and North America. J. Wiley and Sons, New York, 344 pp.

Majka CG, Bousquet Y, Noronha C, Smith ME (2008) The distribution, zoogeography, and composition of Prince Edward Island Carabidae (Coleoptera). The Canadian Entomologist 140: 128-141.

Majka CG, Jackman JA (2006) The Mordellidae Coleoptera. of the Maritime Provinces of Canada. The Canadian Entomologist 138: 292-304.

Majka CG, McCorquodale DB (2006) The Coccinellidae (Coleoptera) of the Maritime Provinces of Canada: new records, biogeographic notes, and conservation concerns. Zootaxa 1154: 49-68.

Majka CG, McCorquodale DB, Smith ME (2007) The Cerambycidae (Coleoptera) of Prince Edward Island: new records and further lessons in biodiversity. The Canadian Entomologist 139: 258-268.

Oygur S, Wolfe GW (1991) Classification, distribution, and phylogeny of North American (north of Mexico) species of Gyrinus Müller Coleoptera: Gyrinidae. Bulletin of the American Museum of Natural History 207: 1-97.

Roberts CH (1895) The species of Dineutes of America north of Mexico. Transactions of the American Entomological Society 22: 279-288 + plates v-vi.

Roughley RE (1991a) Family Haliplidae: crawling water beetles. In: Bousquet Y (Ed) Checklist of Beetles of Canada and Alaska. Agriculture Canada Publication 1861/E: 60-61.

Roughley RE (1991b) Family Gyrinidae: whirligig beetles. In: Bousquet Y (Ed) Checklist of Beetles of Canada and Alaska. Agriculture Canada Publication 1861/E: 72-73.

Roughley RE (1991c) Family Hydrophilidae: water scavenger beetles. In: Bousquet Y (Ed) Checklist of Beetles of Canada and Alaska. Agriculture Canada Publication 1861/E: 130-135.

Roughley RE (2000a) Gyrinidae Latreille, 1810. In: Arnett RH, Jr, Thomas MC (Eds) American Beetles, 1. Archeostemata, Myxophaga, Adephaga, Polyphaga: Staphyliniformia. CRC Press, Boca Raton, 133-137.

Roughley RE (2000b) Haliplidae Aubé, 1836. In: Arnett RH, Jr, Thomas MC (Eds) American Beetles, 1. Archeostemata, Myxophaga, Adephaga, Polyphaga: Staphyliniformia. Boca Raton, Florida: CRC Press, 138-143.

Roughley RE, Larson DJ (2000) Dytiscidae Leach, 1815. In: Arnett RH, Jr, Thomas MC (Eds) American Beetles, 1. Archeostemata, Myxophaga, Adephaga, Polyphaga: Staphyliniformia. Boca Raton, Florida: CRC Press, 156-186.

Shepard WD (2002a) Elmidae Curtis 1830. In: Arnett RH, Jr, Thomas MC (Eds) American Beetles, 1. Archeostemata, Myxophaga, Adephaga, Polyphaga: Staphyliniformia. CRC Press, Boca Raton, 117-120.

Shepard WD (2002b) Dryopidae Billberg 1820. In: Arnett RH, Jr, Thomas MC (Eds) American Beetles, 1. Archeostemata, Myxophaga, Adephaga, Polyphaga: Staphyliniformia. CRC Press, Boca Raton, 121-122.

Sikes DS (2004) The beetle fauna of Rhode Island: an annotated checklist. Kingston, Rhode Island: Rhode Island Natural History Survey 3: 1-296. 
Smetana A (1974) Revision of the genus Cymbiodyta Bed. (Coleoptera: Hydrophilidae). Memoirs of the Entomological Society of Canada 93: 1-113.

Smetana A (1980) Revision of the genus Hydrochara Berth. (Coleoptera: Hydrophilidae). Memoirs of the Entomological Society of Canada 111: 1-100.

Smetana A (1985) Revision of the subfamily Helophorinae of the Nearctic region (Coleoptera: Hydrophilidae). Memoirs of the Entomological Society of Canada 131: 1-154.

Smetana A (1988) Review of the family Hydrophilidae of Canada and Alaska (Coleoptera). Memoirs of the Entomological Society of Canada 142: 1-316.

Van Tassell ER (2000) Hydrophilidae Latreille, 1802. In: Arnett RH, Jr, Thomas MC (Eds) American Beetles, 1. Archeostemata, Myxophaga, Adephaga, Polyphaga: Staphyliniformia. CRC Press, Boca Raton, 187-208.

Vondel BJ van (2005) Haliplidae. In: Nilsson, AN, Vondel BJ van (Eds) World catalogue of insects. Volume 7: Amphizoidae, Aspidytidae, Haliplidae, Noteridae and Paelobiidae (Coleoptera, Adephaga). Apollo Books, Stenstrup, 20-86.

Wright B (1989) The Fauna of Sable Island. Nova Scotia Museum Curatorial Report 68: 1-93.

Appendix I. Coordinates of collection localities

\begin{tabular}{|c|c|c|}
\hline & North latitude & West longitude \\
\hline Brackley Beach & $46^{\circ} 24^{\prime}$ & $63^{\circ} 11^{\prime}$ \\
\hline Cavendish & $46^{\circ} 29^{\prime} 48^{\prime \prime}$ & $63^{\circ} 23^{\prime} 17^{\prime \prime}$ \\
\hline Charlottetown & $46^{\circ} 15^{\prime} 38^{\prime \prime}$ & 63ㅇ $08^{\prime} 37^{\prime \prime}$ \\
\hline Conway Narrows & $46^{\circ} 39^{\prime}$ & $63 \circ 59$ \\
\hline Dingwell's Mills & 46 31'27”' & $62^{\circ} 26^{\prime} 35^{\prime \prime}$ \\
\hline Enmore & $46^{\circ} 35$ & $64^{\circ} 02^{\prime}$ \\
\hline Glenroy & $46^{\circ} 21^{\prime} 10^{\prime \prime}$ & 62० 34'22” \\
\hline Harrington & $46^{\circ} 21^{\prime}$ & $63^{\circ} 10^{\prime}$ \\
\hline Launching & 46० $13^{\prime} 06^{\prime \prime}$ & $62^{\circ} 24^{\prime} 46^{\prime \prime}$ \\
\hline Millvale & $46^{\circ} 24^{\prime} 35^{\prime \prime}$ & $63^{\circ} 25^{\prime} 19^{\prime \prime}$ \\
\hline Mount Herbert & 460 13' 49” & $63^{\circ} 02^{\prime} 14^{\prime \prime}$ \\
\hline New Glasgow & $46^{\circ} 24^{\prime} 36^{\prime \prime}$ & 63 20’ 54” \\
\hline North Rustico & $46^{\circ} 27^{\prime} 25^{\prime \prime}$ & $63^{\circ} 17^{\prime} 55^{\prime \prime}$ \\
\hline Pleasant Grove & $46^{\circ} 22^{\prime} 05^{\prime \prime}$ & $63^{\circ} 03^{\prime} 37^{\prime \prime}$ \\
\hline Rice Point & $46^{\circ} 08^{\prime}$ & $63^{\circ} 15^{\prime}$ \\
\hline St. Patricks & $46^{\circ} 23^{\prime} 55^{\prime \prime}$ & 63 24' 18” \\
\hline Scales Pond & $46^{\circ} 20^{\prime}$ & $63^{\circ} 36^{\prime}$ \\
\hline Souris & $46^{\circ} 21^{\prime}$ & $62^{\circ} 15^{\prime}$ \\
\hline Summerside & $46^{\circ} 23^{\prime}$ & $63^{\circ} 48^{\prime}$ \\
\hline Upton & $46^{\circ} 20^{\prime}$ & $63^{\circ} 32^{\prime}$ \\
\hline Valleyfield & $46^{\circ} 08^{\prime}$ & $62^{\circ} 44^{\prime}$ \\
\hline Vernon River & $46^{\circ} 12^{\prime}$ & $62 \circ 51^{\prime}$ \\
\hline Watervale & $46^{\circ} 15^{\prime} 47^{\prime \prime}$ & $62^{\circ} 53^{\prime} 13^{\prime \prime}$ \\
\hline West Royalty & $46^{\circ} 15^{\prime} 55^{\prime \prime}$ & 6309' 27" \\
\hline Wood Islands & $45^{\circ} 57^{\prime} 27^{\prime \prime}$ & 62o 44’ 55” \\
\hline Woodville Mills & $46^{\circ} 14^{\prime} 26^{\prime \prime}$ & $62^{\circ} 30^{\prime} 46^{\prime \prime}$ \\
\hline
\end{tabular}

